\title{
From Cowpastures to pigs' heads: The development and character of western Sydney
}

\section{Gabrielle Gwyther}

\section{Introduction}

On 27 May 2008 Camden Council voted unanimously 'on planning grounds' to reject the Quranic Society Dar Tahfez El-Quran’s development application for a \$19 million Islamic school on Cawdor Road, Camden. Local residents were triumphant at this turn of events in their campaign of cultural protectionism. Believing that the Islamic school was a cultural incursion too far, the hostilities had become vocal, offensive and at times vicious with the late-night staking of two bloody pigs' heads at the school site, alongside an Australian flag. Upon their triumph, one resident in particular claimed her 15 minutes of fame, declaring:

the ones that come here oppress our society, they take our welfare and they don't want to accept our way of life. ${ }^{1}$

Calling on the name of Macarthur, Camden's most historically prominent family, however, was clearly paradoxical. 'The Macarthurs will be proud of us', she declared, much to the chagrin of some of the Macarthur descendents, who in their rebuttal showed a depth of understanding and clarity that was all but missing outside Camden Council Chambers that night. 'No one can say what their reaction would have been', they wrote to the Sydney Morning Herald.

But we can say that they were first-generation Australians who sought to continue to honour their cultural heritage in a new place and valued education for their children. ${ }^{2}$

From the early colonialists to the contemporary settlement of refugees from north-east Africa and the Middle East, the socio-spatial development of Sydney's west is intertwined with the waves of first-generation Australians seeking to make a new life for themselves and family in an often unsympathetic land, with an unfamiliar language and alien culture. Most first-generation Australians have sought to maintain their native tongue and aspects of their culture. Few, however, have managed to dominate an ancient land and culture quite as proficiently as the Macarthurs and their peers.

Western Sydney is a region of great complexity, a patchwork of culture, language, ethnicity, personal histories, religion, income and status. Taking a chronological developmental approach, this paper examines socio-spatial issues, urban governance and settlement patterns in an attempt to reveal some of the more oblique foundations contributing to the contemporary character of 'Western Sydney' as both a spatial and a cultural signifier of the 'other' Sydney. This paper 
argues that this continuing signification has negative consequences for the political, economic and social life of the region.

\section{The first incursion}

John Macarthur (1767-1834) was a controversial character: a political activist, social climber, recipient of huge land grants and so called 'father' of the Australian wool industry (eternally overshadowing the achievements of his wife Elizabeth). A ruthless lieutenant of the newly formed New South Wales Corps, Macarthur arrived in the New Holland penal colony on the Second Fleet with Elizabeth (1766-1850) and a debt of £500. By 1800 he had apparently transformed the debt into a £20,000 fortune. Governor King assessed Macarthur as a man dedicated to 'making a large fortune, helping his brother-officers to make small ones'.3 Macarthur, it seems, was the original Sydney speculator. In 1806 he took up a large land grant at Cowpastures for the purpose of sheep husbandry. By the 1830s the family had amassed an extensive convict labour force to work its numerous farms, including the 27,333-acre (11,061hectare) Camden Park, after which the township of Camden was later named. ${ }^{4}$

Today, Camden Park House and 960 acres (388.5 hectares) of the estate remain in the possession of Macarthur's descendents. Each September an open day is held to raise money for the property's upkeep, which offers enthusiastic locals a peek into the world of the overseer landlord as well as the lifestyle of its contemporary owner-occupiers. Camden Park symbolises the authority of a colonial age when Anglo-Christian values, individualism and materialism succeeded in dominating an ancient land, its people and their totemic cultures. Since time immemorial the Gandangarra and Dharawal/Tharawal people had inhabited the Cowpastures of south-west Sydney. The initial, friendly curiosity of Aboriginal people towards the early Europeans inevitably developed into great antipathy and resistance, particularly around the Cowpastures where clashes were frequent. On 17 April 1816, on a punitive expedition to track down 'hostile natives', Captain Wallis of the New South Wales Corps oversaw the massacre of 14 Dharawal people, including women and children, camping near Appin. ${ }^{5}$

Camden locals call on their 'colonial' narrative to support their claim to cultural protectionism. Until now the narrative has provided the district with a distinct identity, protecting it culturally and spatially from the seeming ravages of neighbouring hetero-cultural suburbs. The narrative is supported by Camden Council as well as local institutions and organisations. The names of streets, parks and new housing estates chronicle the public affairs of a handful of prominent colonial families, including the Macarthurs, Onslows, Cowpers and Oxleys and more recently the Fairfax family. A campaign advertisement by Wendy Underwood, a local resident, in the lead-up to the 2004 local government election, encapsulates the sentiment: 
But most importantly, we are still a country community that cares, we have not got lost in the multicultural jungle - we have retained old-fashioned Christian values and will stand up for what is right. ${ }^{6}$

Although Camden's contemporary attempts at preserving its cultural 'integrity' have been unusually intense, the historical development and character of Sydney's western suburbs is rooted in local and domestic struggles against successive waves of cultural incursion. What differentiates western Sydney's experience from other parts of Sydney, however, is that these struggles have taken place in a region distinctly disadvantaged in social and physical infrastructure, employment opportunities, educational and cultural facilities, and subject to place-based prejudice.

In contrast to Melbourne, pre-World War I Sydney was a relatively dense, compact city, defined by the terrace and confined by the harbour and limited public transport beyond trams and the omnibus. Frost notes that prior to 1906 the lack of public transport was due, in part, to the domination of the New South Wales parliament by rural interests. ${ }^{7}$ Competition for housing pushed up rents, caused overcrowding and turned less salubrious areas into slums. Frost records that

by 1881 some 83 per cent of the population lived in the central slums and adjoining terrace house suburbs that included Balmain, Leichhardt, Annandale, Glebe, Newtown, Redfern, Erskineville, and Paddington, most within a two mile radius. ${ }^{8}$

Low density suburbs like Strathfield developed around city-centric railway lines to cater for bourgeois families and 'the better class of merchant'. ${ }^{9}$

\section{Creating 'Western Sydney'}

The most intense period of development of Sydney’s western suburbs commenced after World War II when demand for housing outstripped building supplies ${ }^{10}$ and the need for industrial labour was met through postwar immigration programs. The western suburbs became the settling place for families subject to the inner-city slum clearance programs, as well as low-skilled migrants. In the booming economy of the postwar period, rabbit-ridden paddocks between communities clustering around railway stations filled in rapidly with lower-income private and public subdivisions. ${ }^{11}$ Services and even basic infrastructure, like sewerage and kerbing and guttering, were generally an afterthought, if provided at all. ${ }^{12}$ The lack of public transport was premised on the expectation of car ownership, ${ }^{13}$ even though 20 per cent of households in western Sydney were still without a car in $1971 .^{14}$

Distance, in conjunction with a lack of public and private transport facilities, discouraged residents from accessing the recreational and cultural resources the rest of Sydney took for granted. Until the late 1980s, while over a dozen institutions of higher education, including three universities, serviced eastern Sydney, the western suburbs had to be content with five small 
colleges of advanced education, and no university. The University of Western Sydney was not established until 1989. In addition, rather than redistributing health services to the west, vested interests fought to keep hospitals in the city and inner suburbs. In 1966, for instance, the Sydney local government area accounted for only 6 per cent of the metropolitan population but held over a third of the acute illness and obstetric hospital beds. The establishment of Westmead Hospital in 1978 alleviated some of this inequality, however substantial health service restructuring did not occur until the Wran government's bitterly fought 'beds for the west' campaign in the 1980s.

Shortages of construction material in the postwar period meant that suburban housing was generally austere (averaging 4.9 rooms in 1954), ${ }^{15}$ cheaply constructed and frequently jerry-built. Between World War II and the 1970s, fibro cement was the most popular building material for working-class homes. By 1971, some 179,379 fibro dwellings had been constructed in specific 'fibro belts' of Sydney, in contrast to Melbourne's 20,297 such dwellings. ${ }^{16}$ Western Sydney was fibro central. The availability and low cost of the material encouraged owner-building and enabled the easy addition of bedrooms for expanding families in this pre-pill period. Some areas, however, like the 'planned estate' of Winston Hills in the north-west, were established specifically for middle-class families. As West notes, unlike other suburban developments, Winston Hills

was fully serviced, with sewerage, parks and trees already supplied, as well as new shopping centres. ${ }^{17}$

Coinciding with the rise of consumer society and the ensuing socio-economic cleavages that subsequent consumption patterns created, 'Western Sydney' from the outset signified low income, low education levels, homogeneity and disadvantage. Even today, 'Western Sydney' continues to be conceptualised as some amorphous location and culture by the news media and non-residents. Greater western Sydney stretches over nearly 9,000 square kilometres and 14 local council areas (Map 1), and has a population of some 1.79 million people or 43.2 per cent of the Sydney metropolitan total. ${ }^{18}$ It comprises distinct regions (Table 1 ) with different sociodemographic characters, each deserving policy focused on its specific urban issues. Table 2 provides a socio-economic profile of local government areas in greater western Sydney ranked by unemployment rate, which highlights some of the wide regional differences. 


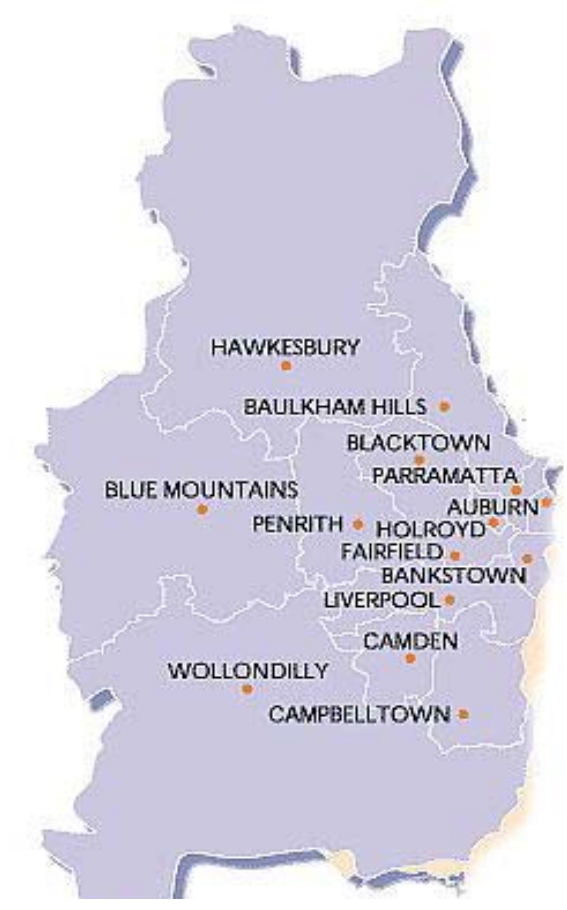

Map 1: Local government areas in greater western Sydney
Table 1: Regions of greater western Sydney

\begin{tabular}{|c|c|}
\hline Regions & Local government area \\
\hline South-west Sydney & $\begin{array}{l}\text { Canterbury } \\
\text { Bankstown } \\
\text { Fairfield } \\
\text { Liverpool }\end{array}$ \\
\hline Outer south-west Sydney & $\begin{array}{l}\text { Campbelltown } \\
\text { Camden } \\
\text { Wollondilly }\end{array}$ \\
\hline Central western Sydney & $\begin{array}{l}\text { Auburn } \\
\text { Parramatta } \\
\text { Holroyd }\end{array}$ \\
\hline Outer western Sydney & $\begin{array}{l}\text { Blacktown } \\
\text { Penrith } \\
\text { (Blue Mountains) }\end{array}$ \\
\hline North-west Sydney & $\begin{array}{l}\text { Baulkham Hills (the 'Hills } \\
\text { District') } \\
\text { Hawkesbury }\end{array}$ \\
\hline
\end{tabular}

Table 2: Socio-economic profile of western Sydney local government areas ranked by unemployment rate

\begin{tabular}{lllllll}
$\begin{array}{l}\text { Local } \\
\text { government } \\
\text { area }\end{array}$ & $\begin{array}{l}\text { Median } \\
\text { household } \\
\text { income }(\$)\end{array}$ & $\begin{array}{l}\text { Median } \\
\text { weekly } \\
\text { rent } \\
(\$)\end{array}$ & $\begin{array}{l}\text { Median } \\
\text { monthly loan } \\
\text { repayment } \\
(\$)\end{array}$ & $\begin{array}{l}\text { Proportion of } \\
\text { rental housing } \\
\text { leased from } \\
\text { housing authority }\end{array}$ & $\begin{array}{l}\text { English } \\
\text { only } \\
\text { spoken }\end{array}$ & $\begin{array}{l}\text { Unemploy- } \\
\text { ment rate }\end{array}$ \\
\hline Fairfield & 873 & 180 & 1,500 & $25.5 \%$ & $27.4 \%$ & $10.5 \%$ \\
Auburn & 906 & 230 & 1,700 & $10.2 \%$ & $22.0 \%$ & $9.1 \%$ \\
\hline Canterbury & 836 & 190 & 1,600 & $16.4 \%$ & $29.8 \%$ & $7.9 \%$ \\
Campbelltown & 1,066 & 185 & 1,500 & $40.3 \%$ & $72.0 \%$ & $7.5 \%$ \\
\hline Bankstown & 926 & 220 & 1,680 & $33.7 \%$ & $43.3 \%$ & $7.4 \%$ \\
\hline Liverpool & 1,082 & 195 & 1,733 & $26.9 \%$ & $47.0 \%$ & $7.1 \%$ \\
\hline Holroyd & 998 & 225 & 1,700 & $18.8 \%$ & $48.5 \%$ & $6.9 \%$ \\
Blacktown & 1,105 & 200 & 1,712 & $31.9 \%$ & $62.1 \%$ & $6.8 \%$ \\
\hline
\end{tabular}




\begin{tabular}{lllllll}
$\begin{array}{l}\text { Local } \\
\text { government } \\
\text { area }\end{array}$ & $\begin{array}{l}\text { Median } \\
\text { household } \\
\text { income } \mathbf{( \$ )}\end{array}$ & $\begin{array}{l}\text { Median } \\
\text { weekly } \\
\text { rent } \\
(\$)\end{array}$ & $\begin{array}{l}\text { Median } \\
\text { monthly loan } \\
\text { repayment } \\
(\$)\end{array}$ & $\begin{array}{l}\text { Proportion of } \\
\text { rental housing } \\
\text { leased from } \\
\text { housing authority }\end{array}$ & $\begin{array}{l}\text { English } \\
\text { only } \\
\text { spoken }\end{array}$ & $\begin{array}{l}\text { Unemploy- } \\
\text { ment rate }\end{array}$ \\
\hline Parramatta & 1,043 & 227 & 1,733 & $21.3 \%$ & $48.8 \%$ & $6.7 \%$ \\
Penrith & 1,147 & 210 & 1,560 & $16.7 \%$ & $81.7 \%$ & $5.3 \%$ \\
\hline Sydney (MSR) & 1,154 & 250 & 1,800 & $15.3 \%$ & $64.0 \%$ & $5.3 \%$ \\
Australia & 1,027 & 190 & 1,300 & $14.9 \%$ & $78.5 \%$ & $5.2 \%$ \\
\hline Wollondilly & 1,186 & 200 & 1,733 & $7.2 \%$ & $90.7 \%$ & $4.3 \%$ \\
\hline Hawkesbury & 1,146 & 205 & 1,626 & $15.8 \%$ & $90.1 \%$ & $4.1 \%$ \\
\hline Camden & 1,353 & 250 & 1,800 & $10.2 \%$ & $88.5 \%$ & $3.9 \%$ \\
Baulkham Hills & 1,732 & 320 & 2,062 & $4.3 \%$ & $72.5 \%$ & $3.2 \%$
\end{tabular}

Source: ABS 2006 Census of Population and Housing Community Profile

In the 1920s, Chicago School social ecologists attempted to explain the spatial growth of the expansionary modern city based on ecological processes. ${ }^{19}$ The expansionary city is characterised by successive waves of people spilling out of areas into others, 'leading to competition between differing communities, and a changing urban form'. ${ }^{20}$ Within the expansionary city 'zones of transition' experience periods of social instability and disorganisation as they undergo the process of socio-economic incursion and succession. In cities like Sydney, which have experienced successive waves of migrant settlement, this process can be particularly acute.

The geographical restrictions of Sydney, which in the postwar period skewed urban expansion westward, away from the Sydney CBD, and more recently to the central coast, intensify this challenging process even further. Geography aside, there is nothing particularly 'natural' about settlement patterns in Sydney's west. In the postwar period, the rollout of low-income subdivisions, in conjunction with the location of migrant hostels, public housing estates and the zoning of industrial land, encouraged the settlement of a disproportionate number of unskilled and socially disadvantaged native-born and immigrant residents. Jupp, McRobbie and York refer to these areas as 'utilitarian suburbs' which 'lacked basic facilities and commercial focal points, but had cheap land and industrial employment'. ${ }^{21}$ From the 1970s central and south-west Sydney became the first-stage settling places for many non-European refugees fleeing political turmoil, particularly from the Middle East, Indochina, South America and north-east Africa, suggesting that large stretches of the region can be considered 'zones of cultural reorganisation'. 
Four positions within the process of cultural reorganisation can currently be identified in western Sydney (see Table 3):

(i) 'middle ring' suburbs which have experienced at least one cycle of cultural reorganisation

(ii) 'middle ring' suburbs characterised by ongoing cultural and ethnic churning

(iii) 'outer ring' suburbs in the early stages of cultural incursion and disorganisation, and

(iv) fringe suburbs like Camden which are under threat of cultural reorganisation.

\section{Table 3: Zones of cultural reorganisation}

\begin{tabular}{|l|l|l|}
\hline $\begin{array}{l}\text { Zone of cultural } \\
\text { reorganisation }\end{array}$ & Description & $\begin{array}{l}\text { Local government area (\% of } \\
\text { population speaking English only), } \\
\text { Primary non-English speaking language } \\
\text { groups. } \\
\text { Sydney Statistical Area (64.0\%) } \\
\text { Australia (78.5\%) }\end{array}$ \\
\hline $\begin{array}{l}\text { (i) Complete cycle of } \\
\text { cultural reorganisation }\end{array}$ & $\begin{array}{l}\text { Suburbs which have experienced at } \\
\text { least one cycle of cultural } \\
\text { reorganisation within the last 50 } \\
\text { years. One or two cultures dominate. } \\
\text { Generally include 'middle ring' } \\
\text { suburbs of Sydney. } \\
\text { Cowterbury (29.8\%) Arabic 14.3\%, } \\
\text { Chinese languages 11.4\%, Greek 10.4\% } \\
\text { Bankstown (43.3\%), Arabic 19.2\%, } \\
\text { Vietnamese 8.3\%. } \\
\text { Fairfield (27.4\%), Vietnamese 17.06\%, } \\
\text { Chinese 1 9.8\%. } \\
\text { Auburn (22.0\%) Chinese 18.3\%, } \\
\text { Arabic 12.4\%, Turkish 7.1\% }\end{array}$ \\
\hline $\begin{array}{l}\text { (ii) Ongoing ethnic and } \\
\text { cultural churning }\end{array}$ & $\begin{array}{l}\text { Suburbs which have a high degree of } \\
\text { cultural and ethnic diversity. No one } \\
\text { culture or ethnicity dominates. } \\
\text { Generally include 'middle ring' } \\
\text { suburbs of western Sydney. } \\
\text { Lower socio-economic areas. }\end{array}$ & $\begin{array}{l}\text { Vietnamese 4.0\%, Italian 3.2\%. } \\
\text { Blacktown (62.1\%), Tagalog 3.6\%, } \\
\text { Arabic 3.2\%, Hindi 2.6\%. } \\
\text { Parramatta (48.8\%), Arabic 10.7\%, } \\
\text { Chinese 10.0\%, Korean 2.1\%. } \\
\text { Holroyd (48.5\%), Arabic 12.5\%, } \\
\text { Chinese 4.8\%, Tamil 2.4\%. }\end{array}$ \\
\hline $\begin{array}{l}\text { (iii) Partial cycle of } \\
\text { cultural reorganisation }\end{array}$ & $\begin{array}{l}\text { Campbelltown (72.0\%), Arabic 2.7\%, } \\
\text { English-speaking cultures dominate, } \\
\text { beginning to settle in moderate } \\
\text { numbers. } \\
\text { Generally involve 'outer ring' } \\
\text { suburbs, to the north and south. } \\
\text { Lower to moderate socio-economic } \\
\text { areas. }\end{array}$ & $\begin{array}{l}\text { Spanish 1.7\%, Samoan 1.7\%. } \\
\text { Baulkham Hills (72.5\%), Chinese } \\
7.2 \% \text { Arabic 1.8, Korean 1.6\%. }\end{array}$ \\
\hline
\end{tabular}




\begin{tabular}{|l|l|l|}
\hline $\begin{array}{l}\text { Zone of cultural } \\
\text { reorganisation }\end{array}$ & Description & $\begin{array}{l}\text { Local government area (\% of } \\
\text { population speaking English only), } \\
\text { Primary non-English speaking language } \\
\text { groups. } \\
\text { Sydney Statistical Area (64.0\%) } \\
\text { Australia (78.5\%) }\end{array}$ \\
\hline $\begin{array}{l}\text { (iv) Threat/fear of } \\
\text { cultural reorganisation }\end{array}$ & $\begin{array}{l}\text { Suburban areas under threat from } \\
\text { cultural incursions and social } \\
\text { disorganisation. } \\
\text { Areas dominated by English speakers } \\
\text { and Anglo-Christian culture on the } \\
\text { outer urban fringe. } \\
\text { Areas of high domestic migration, } \\
\text { particularly of English speakers, and } \\
\text { second- and third-home buyers. }\end{array}$ & $\begin{array}{l}\text { Camden (88.5\%), Italian 1.6\%, } \\
\text { Chinese languages 0.9\%. } \\
\text { Hawkesbury (90.1\%), Maltese 0.7\%, } \\
\text { Italian 0.6\%. } \\
\text { Penrith (81.7\%), Arabic 1.5\%, Italian } \\
0.9 \% .\end{array}$ \\
\hline
\end{tabular}

Source: Australian Bureau of Statistics 2006 Census, Language Spoken At Home by Gender, B12

\section{'Westies'}

To pass the time we kept an eyeball peeled for our dreaded enemies - the Bankies, from the greasy western suburbs. They were easy to spot with their yellow T-shirts, Amco jeans, terrytowelling hats, one-piece swimming costumes, worn-out Coolite surfboards and white Zinc plastered from ear to ear. ${ }^{22}$

During the period of rapid suburbanisation, public intellectuals and artists, including Patrick White, Germaine Greer and Robin Boyd, carelessly branded utilitarian suburbs as places of dreariness and mediocrity. In the case of Barry Humphries, working-class suburbs became a financially rewarding subject of great mirth. Residents of the complex and culturally rich suburbs of western Sydney must still contend with this legacy. One of the more debilitating status signifiers produced during this period was the 'Westie'. ${ }^{23}$ It was a term of division and derision, and became shorthand for a population considered lowbrow, coarse and lacking education and cultural refinement. The 'Westie' developed as a rhetorical device to designate the 'other' Sydneysider: spatially, culturally and economically different from the more prosperous and privileged Sydneysiders of the north and east. As one contemporary resident of Harrington Park in the Camden local government area explained when asked how she felt about moving from Sutherland to the western suburbs:

I wouldn't call this the western suburbs. It's more rural. I wouldn't live in the western suburbs. [Why not?] Well, they're a different type of person. ${ }^{24}$

Derogatory labelling of residents of western Sydney was aided by the social character and cheap aesthetic of large-scale public housing developments, initially at Seven Hills (1958) then at Green 
Valley (1961), Macquarie Fields (1973), Minto (1976), Airds (1977) and Claymore (1978) in the south-west, and the Mt Druitt estates (1966) in the outer west. As Karskens notes, in their

eagerness to produce visually co-ordinated environments as different as possible from unplanned jostling Sydney, [Housing Commission architects] succeeded in creating a vast sameness ... What had been idealistically planned as fair, functional and economical, was roundly condemned as ugly, mean, dangerous and, most ironic of all, Sydney's 'new slums'. ${ }^{25}$

Probably because of its scope, Green Valley came in for particular drubbing. Between 1961 and 1966 the population of the 'Valley' increased from 1,000 to 24,000, with British and native-born settlers predominating. This growth not only doubled the population of Liverpool, but injected a disproportionate number of financially and socially distressed households into the area, placing great pressure on the municipality's limited resources. ${ }^{26}$ John Crawford, Liverpool Council's Town Planner at the time, noted that the Housing Commission 'moved [in] 25,000 people and did not put one swing in'. ${ }^{27}$ Although Housing Commission planners included parks, playing fields and other social infrastructure in the plans for Green Valley, it was left to the struggling local council to actually fund and construct them. For outer urban councils it has been that way ever since. A contemporary resident of Camden who lived in Liverpool during this period explains:

Liverpool was very much like what Camden is now. You knew everybody. That was before Green Valley started. I think I was about 14 or 15 when Green Valley was developed. [So did that change things in Liverpool?] Yeh, a lot more people came into the area... and they brought problems, like they have problems in Campbelltown with Airds and Claymore. ${ }^{28}$

Green Valley brought a degree of notoriety to otherwise sleepy Liverpool. By 1966, about 60 per cent of the population of Green Valley was under 20 years of age. The concentration of such large numbers of young people in the area meant that 'delinquency' was an observable problem and consequently newsworthy. A former resident of 'the Valley', interviewed by Diane Powell, described the 'problem'.

There were just small kids everywhere ... the noise level, not just kid noise but young people driving cars and screeching around corners ... I don't think it was any worse than anywhere else except that there were so many. Like ... I lived five houses up from the corner, there were four children in the corner house, two next door, four in the next one, there were five in the next, and I had five, so five houses, how many's that ... twenty? And it was like that all the way down. ${ }^{29}$

The media unfairly dubbed the suburb 'Dodge City' in reference to the frontier mayhem of the American wild west. However, accusations of delinquency were not confined to Green Valley and Liverpool. Blacktown and Penrith were similarly afflicted, with stories of delinquency peppered through the local papers. In June 1965, for instance, the Penrith Press reported that 'swift action was needed to prevent a juvenile delinquent problem getting out of hand'. ${ }^{30}$ 
During the 1960s, moral panics resulted in Sydney’s western suburbs being viewed as the nursery for juvenile delinquency and a rhetorical relationship developed around the ideas of delinquency, working-class culture and the derogatory term 'Westie'. Arguably, the 'delinquency' problem was more an outcome of the development of youth culture and media interest than of an association between place and behaviour. ${ }^{31}$ The demonising of young people in Sydney's west continues to this day with media representations of ethnic gangs, car-loving hoons, mall rats and teenage mothers, not to mention the spurious belief that suburban youth are more prone to low literacy levels and attention deficit disorders.

Since the early 1980s, the public housing estates of western Sydney have been particularly affected by successive Federal and State government policies of 'residualisation'. Rather than housing a mix of employed and welfare-dependent households - the social housing model - these estates accommodate households likely to be contending with a combination of issues, including physical or mental disability, social isolation, few work skills, language barriers, intergenerational unemployment and social dysfunction. A number of these estates, including Minto and Bonnyrigg, are currently being 'regenerated' through the introduction of private home ownership in the expectation of creating 'social mix'. Rather than acknowledging the relationship between socio-economic structure and disadvantage, this policy continues to promote the causal relationship between poverty and geography that has categorised people in Sydney's west for decades.

\section{Sectarian strife}

I protest against Irishmen coming here and bringing their national grievances to disturb this land of ours ... Until Irishmen learn to be Australian colonists - until they learn to tolerate free discussion - until they understand the uses of liberty, they must not be surprised if people regarded their presence as something not very desirable.

(Henry Parkes, speaking at a rally in Mudgee, January 1872) ${ }^{32}$

If the residents of western Sydney appeared more demographically homogeneous in the 1950s and 1960s, there were still some deep divisions. The contemporary hegemonic term 'AngloCeltic' may seem to portray a mutual history, but the reality was different. As Campion explains it: 'In Australian history, Catholics were the first ethnics. ${ }^{33}$ He was referring here, of course, to the Irish. Catholic-Protestant sectarianism was rife in the early colony and continued until at least the early 1970s. As David Malouf described in his 1998 Boyer lecture:

Catholics and Protestants went to separate schools and learned different versions of history. Secondary students even went to different dancing classes, and when they left school they played football with different clubs, and joined different lodges ... Debutantes came out at different balls. People knew by instinct, at first meeting, by all sorts of tell-tale habits of speech and attitude, who belonged to one group and who to the other. And these divisions functioned institutionally as well as at street level ... Part of the bitterness behind all this was that Catholics 
were almost exclusively Irish, so that the division had an ethnic and historical element as well as a religious one. ${ }^{34}$

Edwards defines sectarianism as 'a complex interaction of religious identity and rivalry, class, ideology and ethnicity'. ${ }^{35}$ Importantly, in terms of the contemporary sectarian troubles affecting western Sydney, he goes on to argue that

sectarianism has been a regular fixture within the armoury of social and political conflict throughout the centuries, serving as a conduit for the expression of not only religious rivalry, but of other social cleavages and grievances, including class and ethnic rivalry. ${ }^{36}$

Whether convict or free settler, the Irish of colonial times comprised a (large) minority ethnic group who brought their fierce sense of national identity with them. While many Protestant Englishmen, including John Macarthur, fashioned themselves into landed gentry in the new country, Irish Catholics were relegated to working-class status, had restricted access to education and were more likely to be found working as farm hands or tenant farmers, than joining the squattocracy. ${ }^{37}$ Notably, Irish names were also over-represented among the bushrangers of the era.

A more subtle version of this spatial division was replicated in the urban environment, so that by the 1930s Protestants dominated the bourgeois suburbs of North Sydney, while Irish Catholics were over-represented in the slums and working-class neighbourhoods of the inner city, ${ }^{38}$ and in settlements around the Georges River, south-west of Sydney. ${ }^{39}$ The 'Irish ascendancy' in the suburbs from Campbelltown through to Bankstown was only interrupted by the socially restructuring effects of the migrant hostels at East Hills and Riverwood in the 1960s. ${ }^{40}$ In the postwar period many Irish Catholics were forced to resettle in Sydney's west and south-west as part of inner-city slum clearance programs. In 1966, for instance, Catholics comprised just under a third of the population of Sydney ${ }^{41}$ but 38 per cent of the new population of Green Valley. Other Irish Catholics were attracted to the cheaper housing offered in western Sydney.

Like most migrant groups, Irish Catholics were determined to maintain their identity, values and culture through homogamy (marrying within the group) and the acculturation of offspring. As a minority group, their establishment of a Catholic school system in the 1880s was integral to this aspiration. Given that the school system was viewed as the maintainer and transmitter of Catholic values and culture, it must also bear some responsibility for the intergenerational reproduction of the Irish working-class habitus and consequent lack of upward mobility amongst this ethnic group prior to the 1960 s. ${ }^{42}$ Campion notes wryly that

the Catholic school system was the Irish bishops' greatest monument. And monuments are costly, not only of money but also of people. ${ }^{43}$ 
A pre-Vatican II Catholic education mostly relied on the financial resources of a submissive IrishAustralian working class, the little 'green catechism' and a band of home-grown and Irish nuns and brothers serving out their mission in Australia. Few of these religious were tertiary trained, and many took out their frustrations on the psyche, palms and calves of their young charges. Even so, compliant Catholic parents continued to send their offspring to these institutions.

In the post-Vatican II period from 1965, with the help of more reliable and substantial government funding, lay teachers began replacing religious en masse. Today the Catholic education system, like other religious and non-religious private schools, is heavily reliant on Federal government funding. The system is more likely to attract wealthier Catholic and nonCatholic families than the Catholics of lower socio-economic status for whom it was originally established. ${ }^{44}$ While anti-Catholicism remains merely a remnant, the prime focus of sectarian conflict in the playground and beyond has shifted toward Muslims.

\section{'Wogs and Dagos'}

'Are you a dago by any chance?' he asked.

I didn't quite understand the meaning of the word 'dago', but I took an educated guess. I thought it might be some nationality pronounced differently in the Australian jargon.

'No, sir, I am a Czech by birth, fresh from England!' I answered enthusiastically although I felt uncomfortable by then.

'Well, we got jobs only for dinki-di Aussies right now, mate, but if you'll try somewhere else, maybe you'll have more luck!' 45

Under the economic and defence-based policy mantra of 'populate or perish' some 2.5 million migrants, mainly from the United Kingdom, Germany, the Netherlands, Poland, Malta, Italy, Greece and the former Yugoslavia, settled in Australia in the two decades following World War II. $^{46}$ Initially, cheap rental housing, in conjunction with an established ethnic presence, in the inner suburbs of Alexandria, Leichhardt, Marrickville, Newtown and Enmore meant they served as first-stage settlement areas for postwar migrants, particularly from southern Europe. ${ }^{47}$ As Burnley explains:

Of mainly unskilled occupations, Southern Europeans had little initial economic choice in standards of housing and older semi-detached and terrace dwelling in inner suburbs attracted new immigrants into declining Australian born working-class areas. ${ }^{48}$

Other migrants had to make do with temporary accommodation in migrant hostels. From the 1960s, however, slum clearance programs and gentrification forced lower-skilled, poorer migrants, as well as native-born Australians, out to cheaper public and private housing in the new subdivisions of Sydney's west.

Yugoslavs, Germans, Austrians, Russians and Italians tended to settle in the Liverpool-Fairfield area where small ethnic concentrations, particularly of Italians, were already established. Maltese 
tended to concentrate around Blacktown, Greystanes, Holroyd and Fairfield, while Greeks displayed a more dispersed pattern of settlement in the suburbs, with a solid presence in Blacktown, as well as the south-western suburbs between Kingsgrove and Bankstown. ${ }^{49}$ Poles settled in numbers in Bankstown and Parramatta. ${ }^{50}$ Between 1947 and 1966 these suburbs experienced immense population growth and social restructuring (Table 4). By 1986 migrants comprised between 20 and 50 per cent of the population of these suburbs. ${ }^{51}$

Table 4: Population growth in western Sydney between 1947 and 1966

\begin{tabular}{|l|l|l|}
\hline Local government area & $\begin{array}{l}\text { Population } \\
1947\end{array}$ & $\begin{array}{l}\text { Population } \\
1966\end{array}$ \\
\hline Bankstown & 42,646 & 159,981 \\
\hline Blacktown & 20,753 & 111,357 \\
\hline Fairfield & 15,987 & 101,226 \\
\hline Holroyd & 24,129 & 65,983 \\
\hline Liverpool & 12,642 & 68,959 \\
\hline
\end{tabular}

Source: P Spearritt and C Demarco, Planning Sydney’s Future, Allen \& Unwin, Sydney, 1988

The influx of Maltese, Italians and Poles increased the proportion of Catholics in Sydney from 21.1 per cent in 1933 to 29.9 per cent in $1971 .^{52}$ Contrary to newspaper headlines at the time, the influx of Polish, Italians and Maltese was not a conspiracy to 'flood Australia' with Roman Catholics. ${ }^{53}$ On the contrary, they diminished the Irish hold over the local church by settling in poorer suburbs of Sydney's west and south-west where Catholic education resources were already strained. ${ }^{54}$ Nevertheless, many migrant parents were not willing to pay for the 'privilege' of private schooling and so began the exodus of lower-income Catholics away from Catholic schools. In 1963 some 30 per cent of Australian Catholic children were in enrolled in state schools, but by the end of the decade this figure had risen to nearly 50 per cent. ${ }^{55}$ Moreover the 'Mediterranean Catholicism' of the Maltese and Italians was 'almost as alien to the old Catholic community as to the non-Catholics'. ${ }^{56}$

The settlement stories of southern European migrants who contributed to national projects like the Snowy Mountains Scheme, mining and the steel industry have been somewhat belatedly acknowledged. Less recognised, however, is the experience of suburban small business owners who had to manoeuvre their way around the restrictions of a foreign business and taxation culture, language deficit and racial prejudice to build up retail and commercial enterprises. For postwar migrants lacking 'recognised' qualifications and skills, the way out of employee servitude or low-paying manual labour was to establish a small business. Neighbourhood mixed businesses, fish and chip shops, shoe shiners and green grocers operated long hours and were cheaply and trustworthily staffed by family. More recent migrant groups, like the Vietnamese, have followed a similar pattern, establishing hot bread shops, Asian groceries, haberdasheries, 
fabric shops and restaurants. Nevertheless, moving beyond the proletariat proved more difficult for the unskilled migrants from southern Europe than for the native-born. As Ware argues:

They start with a much greater disadvantage than merely being at the base of the ladder as the native-born proletariat were. Because of the vast difference between the education and occupational skills of southern European-born and even the most disadvantaged of the nativeborn, the bottom rung of the ladder has effectively been removed. ${ }^{57}$

This has been a recurring experience for more recent low-skilled, non-English speaking migrants. For many, social advancement has been even further compromised by the industrial restructuring of the past 20 years and an unforgiving global economy. Inexplicably little recognition has been given to this issue. Migrants have generally been left to get on with 'it'- economic and social integration $^{58}$ - and any lack of achievement is likely to be viewed as either a cultural or individual deficit.

\section{Non-European migration and the multicultural neighbourhood}

Be good, little migrants

We've saved you from starvation

War, landlessness, oppression

Just display your gratitude

But don't be heard, don't be seen ${ }^{59}$

From Federation to 1973 the White Australia policy (set out in the Immigration Restriction Act 1901) and the 'dictation test' restricted non-European migration. The policy was underpinned by the notion of assimilation, in which 'new Australians' were expected to conform to an indeterminate idea of Anglo-Australian culture and values. This policy was premised on the superiority of cultural homogeneity and the notion that some cultures, namely western European ones, were more amenable to assimilation than other cultures.

The overtly racist nature of assimilation was tempered from 1966 with the introduction of integrationist policies which supported the assertion of ethno-cultural rights, ethnic community organisations and government-funded English lessons for non-English speaking children. This laid the groundwork for the policy shift in the 1970s towards an 'ethnic group'-based model of multiculturalism. Although a positive move, such a model nevertheless, denies the complexity and difference in 'ethnic' experience and identity. Ethnic communities councils were established under the Whitlam Labor government of 1972-75, but it was the conservative Fraser Government that followed which 'espoused the ideology of cultural pluralism' ${ }^{60}$ on economic grounds and supported this by permitting large-scale Asian and non-European migration.

This was in keeping with the history of Australia's postwar immigration program which has invariably been a history of labour migration. With unfortunate economic timing, the mass entry of low-skilled, impoverished refugees from south-east Asia and the Middle East commenced on 
the cusp of a period of global restructuring. This period was witness to economic deregulation, industrial reorganisation, a retargeting of government expenditure and a contracting welfare state. This has resulted in the formation of certain ethnic communities of structural deprivation, particularly in south-west Sydney.

Arguably, the two migrant groups which have most challenged suburban life in western Sydney in the period of multiculturalism have been the Indochinese and people from the Middle East, many of whom arrived as refugees, usually under harrowing circumstances. The first Vietnamese refugees entered Australia in 1975 in the wake of the Vietnam War and unification under the communists. They comprised two primary ethnic groups: ethnic Chinese who made up 34 per cent of Vietnamese settlers at the 1986 Census and who, as traditional sojourners, already had established Chinese communities in Australia; and ethnic Vietnamese who now form the second largest Asian group in Australia after the ethnic Chinese. ${ }^{61}$ A smaller number of Laotians and Cambodians also arrived as refugees in the late 1970s following political upheaval in south-east Asia.

The mass settlement of relatively unskilled, non-English speaking and often traumatised Indochinese in Australia between 1975 and 1982 challenged the government's migration policies and its Euro-Western preoccupation. At the suburban level, the Vietnamese challenged the notion of what it was to be Australian. They unwittingly confronted the suburban status quo through their concentrated settlement patterns, particularly within the Fairfield and Bankstown local government areas. Their Asian appearance and languages, temples, religious festivals, nonEnglish shop signage (a particularly sensitive issue in Sydney's west), and the fear of drug lords and 'triads' have challenged suburban identities. Particularly in the early years of settlement, the Indochinese experienced extremely high levels of unemployment. Drawing on Department of Social Security figures, Lee notes, for instance, that 55.3 per cent of Vietnamese arriving in Australia in 1989-90 and 70 per cent of those arriving 1990-91 were still receiving unemployment benefits in 1994, four years later. ${ }^{62}$ Although there are stories of social mobility and economic success, a disproportionate number of Indochinese have experienced 'mobility blockage' for a range of reasons - incongruous employment skills, language difficulties, and in some cases employee exploitation as outworkers. The psychological impact of their dislocation experience may also have been a factor.

During the 1980s and 1990s, the media exploited the fear of 'exotic' Vietnamese criminality through its focus on Cabramatta. As Dreher explains:

There has been a long history of media interest in the suburb, with stories on 'Asian immigration' and teenage gangs' heroin dealing, refugees and illegal immigrants, all mixed up with reports about multiculturalism and exotic cuisines. ... Cabramatta is often referred to as 'Australia's heroin capital' and hidden camera footage of drug deals at the railway station and in the shopping centre are familiar sights to most television watchers. ${ }^{63}$ 
The events of 11 September 2001 brought some much-needed relief to residents of Cabramatta as the media refocused its attention on the Muslim 'problem' in Bankstown. This shift in media focus has assisted in Cabramatta's recent rehabilitation as a multicultural success story of sorts a tourist attraction, an exotic 'eat street' and stage for the annual big bang of Chinese New Year. Beyond this, however, Cabramatta, like many suburbs of Sydney's west, is a tribute to human resilience and creativity as residents surmount the financial, emotional and cognitive difficulties of a foreign land, language, education system and culture.

In the pre- and postwar periods, Christian Lebanese migrants (Maronite, Melkite and Antiochian Orthodox) were generally well-educated and engaged in entrepreneurial, professional and technical occupations. Their more recent Muslim compatriots, many of whom arrived through the family reunion scheme following civil strife in Lebanon, are more likely to be employed as unskilled workers or unemployed. ${ }^{64}$ This latter group and their offspring are disproportionately concentrated amongst the poor and low-income families of Australia. It has been argued that Muslim Lebanese are more visible within the wider community due to their concentration in the suburbs of Lakemba, Punchbowl, Bankstown, Auburn and Harris Park. ${ }^{65}$ With reference to more recent events, Collins argues that Lebanese visibility is related to 'media portrayals of Lebanese crime', ${ }^{66}$ although it is hard to divorce the events of September 11 from this alarmist media attention.

Racism is a major force in the lives of Lebanese Australians and even more so for young, secondgeneration Muslim men. In the classic intersection of minority ethnicity, age and gender, a proportion of these young men have responded by adopting a type of 'ethnic masculinity'. According to Poynting, Tabar and Noble,

this involves asserting what for them constitutes their Lebaneseness in Australia, and doing so with a good deal of male aggression, often directed at authority figures from the 'mainstream' culture which are implicated in institutional racism. ${ }^{67}$

However, it also suits us to view problems involving young Muslim men from a cultural or ethnic perspective and to ignore their social, political and economic disadvantage. The generally poor understanding of Australians about the internationality and complexity of Islam tends to reduce religion, language, culture and nationality to a single entity, captured in the nuanced phrase 'of Middle Eastern appearance', maddening cultural and ethnic groups and adding to their feelings of frustration and ostracism from the wider society.

This issue plays out vividly across Sydney, as evidenced by the so-called 'Cronulla riots' of 11 December 2005. ${ }^{68}$ While the targeting of 'people of Middle Eastern appearance' in Cronulla that particular weekend might seem an aberration, beach-going residents of western Sydney have been enduring the intolerance of coastal residents since well before Puberty Blues. ${ }^{69}$ In this more 
recent incident, however, race seemed an easier target for both the media and coastal dwellers than social class, although masculine indignation and bravado remain constant on both sides.

Whether part of the European wave of migration under the assimilation policy in the immediate postwar period, or the non-European wave under multiculturalism from the 1970s, migrant settlement patterns have at least one thing in common: better skilled, more highly resourced ethnic groups have settled in Sydney's better heeled northern and eastern suburbs; while less skilled, poorly resourced migrants have made their homes in the suburbs of west and south-west Sydney.

\section{The 'Aspirationals'}

It's started to change Ingleburn to a Cabramatta-type place. And the same thing in Liverpool. Once they get an influx it's like it changes the outlook of the place. Hurstville is a prime example. It used to be a beautiful place, but it's changing. It's going down the tubes the way it is going with all the shops that are around. It makes the area look grubby, dirty, unclean. [Male resident of Camden local government area who had recently moved from Ingleburn] ${ }^{70}$

Sometime during the Hawke-Keating Labor government's reign between 1983 and 1996, a subtle shift in support for multiculturalism began. The Fitzgerald Report ${ }^{71}$ was critical of the selection criteria in immigration policy, and emphasised the dangers of multiculturalism to social cohesion. Immigration was reduced, and cuts were made to multicultural programs on the grounds of economic rationalism. This development increased from 1996 with the Howard government's visible withdrawal of commitment to multiculturalism, particularly after the rise of the ultraconservative One Nation party, with its populist hostility to Asian immigration and multiculturalism.

It was during this 'post-multicultural' period that a constituency of Anglo-Australian residents variously dubbed 'Howard's Battlers' and later 'Aspirationals' decamped from the multicultural suburbs of Sydney's west and south-west to settle in homogenous residential enclaves on the 'new' urban fringe. This process has been dubiously referred to as 'white flight' ${ }^{72}$ The term was initially used in the 1960s to describe race-based urban segregation in the United States, where 'white' families fled from their inner-city neighbourhoods, often in the middle of the night, in fear of 'black' infiltration. ${ }^{73}$ They resettled on the fringes of the cities in suburbs which, as Ray Hanania explains, were not the high-status suburbs they are today. ${ }^{74}$ Reflecting on his own family's flight from South Shore Valley, Chicago, in 1968, Hanania explains:

We fled before we even knew what we were fleeing from ... The truth was, most people who fled from the city's South Side did so to escape a nightmare vision of racial turmoil, fed by the media, fuelled by the uncertainty of the times, and prodded along to protect what was left of their treasured 'nest eggs'. Fear drove them, not reality. 
To use the term 'white flight' in the Sydney context is inflammatory. Moreover it conceals the complexity of forces encouraging some residents to relocate to more homogeneous suburbs, mostly master-planned communities (MPCs), on the outskirts of western Sydney.

The term 'Aspirationals' came to prominence in the late 1990s to describe a seemingly new political constituency living on Sydney's urban fringe, who appeared to have clawed their way out of suburbs and into big cars, big houses and big mortgages. As the one-time leader of the federal Labor party, Mark Latham, ${ }^{75}$ both promulgated and epitomised, Sydney's aspirationals are mostly 'Westies', just all grown up and taking advantage of dual incomes, easy finance and housing-based wealth. Developed typically for second- and third-home-buying, middle-income households in conventionally lower-income regions like Sydney's outer west, the MPC is a cultural artefact which encapsulates the fears, ambitions and way of life of the aspirational constituency. The MPC promotes a particular ideological form of community, one which is used to buttress residents' social, physical and economic security in a variable and changing region like western Sydney. ${ }^{76}$

Research into the issues which influenced the decision of residents to relocate into MPCs in Camden local government area indicates that although significant, the desire to move away from multicultural suburbs was but one factor. ${ }^{77}$ They also wanted to move away from low-income neighbourhoods and disorderly public housing estates; they expected that buying into a new, economically and culturally homogeneous estate would better protect their property value; they wanted to move into neighbourhoods reminiscent of their own childhoods and to exhibit status and success through residential exclusivity. As one Camden resident explained when asked what motivated his purchase in Garden Gates:

It was a nice new estate. The houses appeared to be of a similar size. Large houses. There were no housing commission problems out here, because it's away from all that. ${ }^{78}$

The development of higher income, 'Aspirational' enclaves in western Sydney indicates the strengthening of socio-spatial polarisation at both regional and local scales within Sydney. Although there is some concern about this development at the national level, it can also be argued that the economy and social fabric of western Sydney is strengthened by a mix of incomes, job types and employment opportunities. This may help to ensure that it retains its talent, knowledge, creativity, wealth and established social networks, and is able to offer the range of social, cultural and economic opportunities that the rest of Sydney takes for granted. Nevertheless, such a perspective must rest on an understanding of the structural and spatial disadvantage that affects certain social groups and areas of western Sydney, and on an agenda that supports lower socioeconomic and marginalised social groups to realise full social citizenship - with its economic, political and civic elements. 


\section{Conclusion: harnessing the diversity and complexity of Sydney's west}

Postwar Sydney has witnessed very little urban unrest compared to some European and American cities which have experienced the upheaval of ethnic succession and cultural reorganisation. ${ }^{79}$ Recent incidents have one important feature in common; they involve socially, politically and economically marginalised youth, whether young Aboriginals in the 'Redfern riots' of 2004, the white, unemployed youth involved in the Macquarie Fields riots in February 2005, or the Muslim youth butting up against the dominant culture in Cronulla in late 2005. Hopes and aspirations for a multicultural society, not least as promulgated by the cultural industry itself, in conjunction with the hegemony of neo-liberalism and its valuing of individualism, have tended to obscure the socio-structural issues and the fact that some individuals and groups are so poorly positioned within the socio-economic strata that they inevitably experience 'mobility blockage'.

It is remarkable that a disparate region like western Sydney, with its social complexity, pockets of social disadvantage and high concentrations of first- and second-generation migrants, has in the main been able to maintain a sense of stability and social cohesion. Until recently, the development of western Sydney, with its low density and detached housing in conjunction with the systematic release of land on the fringe for lower income, residential development, has worked to alleviate suburban pressure points and population displacement.

Over the past two decades, this equation has been disrupted by the scarcity of new land releases despite continuing population growth, primarily from migration. Other factors include the displacement of first home-buyer subdivisions on the urban fringe by new master-planned communities designed for higher income and second- and third-home buyers, the residualisation of public housing, and the lack of creative policies and support for low-income migrants that just might have enabled them to claim a more meaningful part of Australia's decade of 'boom' economy.

Over the next 25 years, western Sydney is expected to receive 400,000 new residential dwellings; 160,000 new homes in greenfield sites in the north-west and south-west sectors, and the rest from urban renewal and densification programs in existing suburbs. ${ }^{80}$ Such growth will inevitably increase pressure on local and regional social and physical infrastructure, as well as intensify socio-economic and cultural reorganisation.

Policy makers, planning strategists and government treasurers must heed the lessons of western Sydney's postwar development to assure social cohesion amongst disparate groups, as well as a more equitable distribution of resources and opportunity. With regard to equitable distribution, they could start for instance, by querying the social outcomes of the 'Plan for Sydney's Future' ${ }^{81}$ which supports the strengthening of high-tech employment opportunities in Sydney's 'global arc' from Macquarie Park to Sydney Airport, but is planning to merely increase 'jobs' by setting aside more industrial land in Sydney’s ‘utilitarian’ west. Such planning will inevitably entrench the 
perception of 'Western Sydney' as a low-skilled, lower socio-economic region, which has consequences for public and private investment and for the lived experience of residents of Sydney's west.

Gabrielle Gwyther is a post-doctoral Research Fellow in the Social Justice, Social Change Research Centre at the University of Western Sydney

\section{Endnotes}

${ }^{1}$ McCulloch, cited in D Murphy, 'Am I the new Pauline Hanson? I hope so', Sydney Morning Herald, 31 May 2008, p 1

${ }^{2}$ H Finlay and Macnell family, Letters to the Editor, Sydney Morning Herald, 2 June 2008, p 12

${ }^{3}$ K Buckley and T Wheelwright, No paradise for workers: Capitalism and the Common People in Australia 1788-1914, Oxford University Press, Melbourne, 1988, p 36

${ }^{4}$ A Atkinson, Camden: Farm and Village Life in Early New South Wales, Oxford University Press, Melbourne, 1988

${ }^{5}$ V Fowler, Massacre at Appin 1816, Campbelltown and Airds Historical Society Inc, Campbelltown NSW, 2005

${ }^{6}$ Camden Advertiser, 17 March 2004, p 15

${ }^{7}$ L Frost, 'Suburbia and Inner Cities' in A Rutherford (ed), Populous Places: Australian Cities and Towns, Dangaroo Press, Sydney, 1992, pp 190-197

${ }^{8}$ L Frost, 'Suburbia and Inner Cities' in A Rutherford (ed), Populous Places: Australian Cities and Towns, Dangaroo Press, Sydney, 1992, p 193

${ }^{9}$ W F Morrison, Aldine Centennial History of New South Wales, Aldine Publishing Company, Sydney, 1888

${ }^{10}$ P West, A History of Parramatta, Kangaroo Press, Kenthurst NSW, 1990

${ }^{11}$ G Gwyther, 'Once Were Westies’, Griffith Review: Cities on the Edge, 20, 2008, pp 153-164

${ }^{12}$ P Spearritt and C Demarco, Planning Sydney’s Future, Allen \& Unwin, Sydney, 1988

${ }^{13}$ M Neutze, People and Property in Bankstown, Urban Research Unit, Australian National University, Canberra, 1971

${ }^{14}$ P Spearritt and C Demarco, Planning Sydney’s Future, Allen \& Unwin, Sydney, 1988

${ }^{15}$ G Karskens, Holroyd: A Social History of Western Sydney, New South Wales University Press, Sydney, 1991

${ }^{16}$ P Spearritt, 'Statistical Tables' in J Davidson (ed), The Sydney-Melbourne Book, Allen \& Unwin, Sydney, 1986

${ }^{17}$ P West, A History of Parramatta, Kangaroo Press, Kenthurst, Sydney, 1990

${ }^{18}$ Australian Bureau of Statistics, 2006 Census of Population and Housing: Community Profile at http://www.abs.gov.au/websitedbs/d3310114.nsf/Home/census 2007 and Office of the Minister for Western Sydney, About Western Sydney, at http://www.westernsydney.nsw.gov.au, accessed 10 July 2008

${ }^{19}$ RE Park and EW Burgess, The City: Suggestions for Investigation of Human Behaviour in the Urban Environment, University of Chicago, Chicago, 1967 


\section{Endnotes}

${ }^{20}$ M Savage and A Warde, Urban Sociology, Capitalism and Modernity, Macmillan, London, 1993, p 10

${ }^{21}$ J Jupp, A McRobbie and B York, 'Metropolitan Ghettoes and Ethnic Concentrations: Working Papers on Multiculturalism No 1', Office of Multicultural Affairs, University of Wollongong, 1990, p 21

${ }^{22}$ K Lette and G Carey, Puberty Blues, McPhee Gribble, Carlton, 1979, p 3

${ }^{23}$ G Gwyther, 'Once Were Westies', Griffith Review: Cities on the Edge, 20, 2008, pp 153-164

${ }^{24}$ G Gwyther, 'Paradise Planned: Community Formation and the Master Planned Estate', PhD thesis, University of Western Sydney, 2004, p 215

${ }^{25}$ G Karskens, Holroyd: A Social History of Western Sydney, New South Wales University Press, Sydney, 1991, p 223

${ }^{26}$ T Brennan, New Community: Problems and Policies, Angus and Robertson, Sydney, 1973

${ }^{27}$ cited in C Keating, On the Frontier: A Social History of Liverpool, Hale \& Iremonger, Sydney, 1996, p 198

${ }^{28}$ G Gwyther, 'Paradise Planned: Community Formation and the Master Planned Estate’, PhD thesis, University of Western Sydney, 2004, p 192

${ }^{29}$ D Powell, Out West: Perceptions of Sydney's Western Suburbs, Allen \& Unwin, St Leonards, 1993, p 87, italics added

${ }^{30}$ P West, The Secret Lives of Men: Growing Up in Penrith 1920-1992, University of Western Sydney, Nepean, 1992, p 56

${ }^{31}$ G Gwyther, 'On Politics, Sport and "Coming the Knuckle"“ ‘ in N Tsoutas (ed), A Show About Joe, Casula Powerhouse Arts Centre, Liverpool, 2007, pp 9-19

${ }^{32}$ P O'Farrell, The Irish in Australia: 1788 to the Present, University of New South Wales Press, Sydney, 2000, first published 1986

${ }^{33}$ E Campion, Rockchoppers: Growing Up Catholic in Australia, Penguin Books, Ringwood Vic, 1982, p 3

${ }^{34}$ D Malouf, 'Lecture 6: A Spirit of Play’ in Boyer Lectures, ABC Books, Sydney, 1998

${ }^{35}$ B Edwards, 'Proddy-Dogs, Cattleticks and Ecumaniacs: Aspects of Sectarianism in New South Wales, 1945-1981', PhD thesis, University of New South Wales, 2007

36 B Edwards, 'Proddy-Dogs, Cattleticks and Ecumaniacs: Aspects of Sectarianism in New South Wales, 1945-1981', PhD thesis, University of New South Wales, 2007

${ }^{37}$ AL Greiner and Jordan-Bychkov, Anglo-Celtic Australia: Colonial Immigration and Cultural Regionalism, Centre for American Places, Santa Fe, 2002; J Jupp, Ethnic and Cultural Diversity in Australia, Australian Bureau of Statistics (ed), 13010 Year Book Australia, 1995, Canberra, 1995

${ }^{38} \mathrm{H}$ Mol, The Faith of Australians, George Allen \& Unwin, Sydney, 1985

${ }^{39}$ M Hogan, The Sectarian Strand: Religion in Australian History, Penguin, Ringwood Vic, 1987

${ }^{40}$ H Goodall, S Wearing, D Byrne and J Kijas, 'Recognising Cultural Diversity: The Georges River Projects in South-western Sydney', Sustainability and Social Science Round Table, Institute for Sustainable Futures and CSIRO Minerals, Sydney, 2004

${ }^{41}$ T Brennan, New Community: Problems and Policies, Angus \& Robertson, Sydney, 1973

${ }^{42}$ L Foster and K Harman, Australian Education: A Sociological Perspective, Prentice Hall, Sydney, 1992 


\section{Endnotes}

${ }^{43}$ E Campion, Rockchoppers: Growing Up Catholic in Australia, Penguin Books, Ringwood Vic, 1982, p 70

${ }^{44}$ Bishops of NSW and the ACT, 'Schools at a Crossroads: Pastoral Letter of the Bishops of NSW and the ACT’, Catholic Education Office, Sydney, 2007

${ }^{45}$ J Holman, The Aussies: They're a Weird Lot, ML Enterprises, Edgecliff NSW, 1980, p 22

${ }^{46}$ P O’Farrell, The Catholic Church and Community: An Australian History, New South Wales University Press, Kensington NSW, 1992

${ }^{47}$ A M Tamis, An Illustrated History of the Greeks in Australia, Darsalis Archives of the Greek Community, La Trobe University, Melbourne, 1997; J Collins, K Gibson, C Alcorso, S Castles and D Taid, A Shop Full of Dreams - Ethnic Small Business in Australia, Pluto Press Australia, Sydney, 1995

${ }^{48}$ cited in B Badcock, 'The Residential Structure of Metropolitan Sydney', Australian Geographic Studies, vol 11, 1973, pp 1-27

${ }^{49}$ J Collins, K Gibson, C Alcorso, S Castles and D Taid, A Shop Full of Dreams - Ethnic Small Business in Australia, Pluto Press Australia, Sydney, 1995

${ }^{50}$ P West, A History of Parramatta, Kangaroo Press, Kenthurst NSW, 1990

${ }^{51}$ G Karskens, Holroyd: A Social History of Western Sydney, New South Wales University Press, Sydney, 1991

${ }^{52}$ P Spearritt, 'Statistical Tables’ in J Davidson (ed), The Sydney-Melbourne Book, Allen \& Unwin, Sydney, 1986

${ }^{53}$ E Campion, Rockchoppers: Growing Up Catholic in Australia, Penguin Books, Ringwood Vic, 1982, p 99

${ }^{54}$ G Karskens, Holroyd: A Social History of Western Sydney, New South Wales University Press, Sydney, 1991

${ }^{55}$ P O’Farrell, The Irish in Australia: 1788 to the Present, University of New South Wales Press, Sydney, 2000, first published 1986

${ }^{56}$ G Karskens, Holroyd: A Social History of Western Sydney, New South Wales University Press, Sydney, 1991, p 213

${ }^{57} \mathrm{H}$ Ware, 'The Social and Demographic Impact of International Immigrants on Melbourne: A Study of Various Differentials' in IH Burnley (ed), Urbanization in Australia: The Post-war Experience, Cambridge University Press, Cambridge, 1974, pp 185-199, p 198

${ }^{58}$ P West, A History of Parramatta, Kangaroo Press, Kenthurst NSW, 1990

${ }^{59}$ U Loewald, 'Be Good, Little Migrants' in A Pung (ed), Growing Up Asian in Australia, Black Inc, Melbourne, 2008, pp 225-226

${ }^{60}$ S Castles, M Kalantzis, B Cope and M Morrissey, Mistaken Identity: Multiculturalism and the Demise of Nationalism in Australia, Pluto Press Australia, Sydney, 1988 p 65

${ }^{61}$ N Viviani, The Long Journey: Vietnamese Migration and Settlement in Australia, Melbourne University Press, Melbourne, 1984; GY Lee, 'Indochinese Refugees Families in Australia: A Multicultural Perspective', Cultural Diversity and the Family: Volume 3, Ethnic Affairs Commission of New South Wales, Ashfield, 1997 


\section{Endnotes}

${ }^{62}$ GY Lee, 'Indochinese Refugees Families in Australia: A Multicultural Perspective', Cultural Diversity and the Family: Volume 3, Ethnic Affairs Commission of New South Wales, Ashfield, 1997

${ }^{63}$ T Dreher, 'Cabramatta News Talk: Audiences, Identity and Symbolic Power' in J Collins and S Poynting (eds), The Other Sydney: Communities, Identities and Inequalities in Western Sydney, Common Ground Publishing, Melbourne, 2000, pp 106-122

${ }^{64}$ J Collins, 'From Beirut to Bankstown: The Lebanese Diaspora in Multicultural Australia' in P Tabar (ed), Lebanese Diaspora: History, Racism and Belonging, Lebanese American University, Beirut, 2005, pp 187-212

${ }^{65}$ J McKay, Phoenician Farewell: Three Generations of Lebanese Christians in Australia, Ashwood House Academic, Melbourne, 1989

${ }^{66}$ J Collins, 'From Beirut to Bankstown: The Lebanese Diaspora in Multicultural Australia' in P Tabar (ed), Lebanese Diaspora: History, Racism and Belonging, Lebanese American University, Beirut, 2005, pp 187-212

${ }^{67}$ S Poynting, P Tabar and G Noble, 'Representations of Youth in Sydney: A Critique of Liberal Rhetoric about Young Lebanese Immigrants' in P Tabar (ed), Lebanese Diaspora: History, Racism and Belonging, Lebanese American University, Beirut, 2005, pp 213-249

${ }^{68}$ S Poynting, “Thugs' and 'Grubs' at Cronulla: From Media Beat-ups to Beating up Migrants' in S Poynting and G Morgan (eds), Outrageous! Moral Panics in Australia, ACYS Publishing, Hobart, 2007, pp 158-170

${ }^{69}$ K Lette and G Carey, Puberty Blues, McPhee Gribble, Carlton, 1979

${ }^{70}$ G Gwyther, 'Paradise Planned: Community Formation and the Master Planned Estate', PhD thesis, University of Western Sydney, 2004, p 194

${ }^{71}$ Committee to Advise on Australia’s Immigration Policies, Immigration: A Commitment to Australia Australian Government Publishing Service, Canberra, 1988

${ }^{72}$ See for instance M Latham, From the Suburbs: Building a Nation from our Neighbourhoods, Pluto Press Australia, Annandale, 2003

${ }^{73}$ MA Herman, Fighting in the Streets: Ethnic Succession and Urban Unrest in Twentieth-Century America, Peter Lang, New York, 2005

${ }^{74}$ R Hanania, Midnight Flight: One family's experience of White Flight and the racial transformation of Chicago's South Side, the author, 2000, http://www.hanania.com/flight/flight.htm, accessed 10 July 2008

${ }^{75}$ M Latham, From the Suburbs: Building a Nation from our Neighbourhoods, Pluto Press Australia, Annandale, 2003

${ }^{76}$ G Gwyther, 'Once Were Westies’, Griffith Review: Cities on the Edge, 20, 2008, pp 153-164

${ }^{77}$ G Gwyther, 'Paradise Planned: Community Formation and the Master Planned Estate’, PhD thesis, University of Western Sydney, 2004

${ }^{78}$ G Gwyther, 'Paradise Planned: Community Formation and the Master Planned Estate', PhD thesis, University of Western Sydney, 2004

${ }^{79}$ MA Herman, Fighting in the Streets: Ethnic Succession and Urban Unrest in Twentieth-Century America, Peter Lang, New York, 2005 


\section{Endnotes}

${ }^{80}$ New South Wales Department of Planning, Metropolitan Strategy: Cities of Cities, A Plan for Sydney's Future, Sydney, 2005

${ }^{81}$ New South Wales Department of Planning, Metropolitan Strategy: Cities of Cities, A Plan for Sydney's Future, Sydney, 2005 